\title{
ARTICLE \\ Marine fungoid producers of DHA, EPA and carotenoids from central and southern Chilean marine ecosystems
}

\author{
Fungoides marinos productores de DHA, EPA y carotenoides provenientes \\ del ecosistema marino de Chile central y sur-austral
}

\begin{abstract}
Natalie L. Pino ${ }^{1,2,3}$, Cristian Socias ${ }^{1,2}$ and Rodrigo R. González ${ }^{1,2,3}$
${ }^{1}$ Unidad de Biotecnología Marina, Facultad de Ciencias Naturales y Oceanográficas, Universidad de Concepción, Barrio Universitario $\mathrm{S} / \mathrm{N}$, Concepción, Chile

${ }^{2}$ Centro de Investigación Oceanográfica del Pacífico Sur-Oriental, Programa COPAS Sur Austral, Universidad de Concepción, Concepción, Chile

${ }^{3}$ Doctorado en Ciencias con mención Manejo de Recursos Acuáticos Renovables (MaReA), Facultad de Ciencias Naturales y Oceanográficas, Universidad de Concepción, Barrio Universitario S/N, Concepción, Chile. napino@udec.cl
\end{abstract}

\begin{abstract}
Resumen.- La creciente demanda de ácidos grasos poliinsaturados (AGPI) provocada por la escasez de pesca extractiva, ha impulsado la obtención de fuentes alternativas sustentables para abastecer su mercado. Los Thraustochytridos y levaduras marinas (fungoides marinos), son potenciales productores de lípidos y carotenoides de importancia comercial. Desde una colección de 41 cepas de fungoides marinos aisladas en el Sistema de Corriente de Humboldt, se determinó la capacidad de producir DHA (ácido docosahexanoico), EPA (ácido eicosapentanoico) y CT (carotenoides totales) en cultivos líquidos comercial (MS) y alternativos (PDB, GAM, BAM y MCM). Los resultados indican que el medio MS y PDB, presentaron las mayores velocidades de crecimiento $\left(0,02 \mathrm{~h}^{-1}\right)$. No obstante, el medio MS presenta estos parámetros cinéticos a $16 \circ \mathrm{C}$ y el PDB a $37^{\circ} \mathrm{C}$. Trece de las cepas analizadas presentaron una alta capacidad para producir DHA (hasta $23 \%$ peso seco) у CT (hasta $18 \%$ peso seco), comparables a los niveles observados en Schizochytrium sp. KH105 y Rhodosporidium toruloides. Adicionalmente, todas las cepas ensayadas también produjeron pequeñas cantidades de EPA (hasta $0,3 \%$ peso seco). La microscopia electrónica revela que la cepa C36 es morfológicamente consistente con levaduras y su secuencia parcial del gen ribosomal $18 \mathrm{~s}$ presenta un $97 \%$ de similitud con el género Rhodotorula, el que hasta ahora no ha sido reportado como productor de DHA y EPA. Finalmente, las cepas C36, C22 y C4 son interesantes objetos de estudio para escalar su producción y proyectar su uso comercial, como por ejemplo para suplementar en omega-3 y carotenoides alimentos para consumo humano, animales de corral o para estadios larvales de peces cultivados y pigmentar la carne del salmón, entre otros.
\end{abstract}

Palabras clave: Fungoides marinos, DHA, EPA, carotenoides totales, Rhodotorula, parámetros cinéticos

\begin{abstract}
Declining fishing yields have pushed the search for sustainable alternative sources for polyunsaturated fatty acids (PUFAs). Thraustochytrids and marine yeasts (marine fungoid protists) are potential commercial sources of lipids and carotenoids. It was determined the capacity of a collection of 41 strains of marine fungoid isolated in the Humboldt Current System, to produce DHA (docosahexanoic acid), EPA (eicosapentanoic acid) and CT (total carotenoids) in commercial growing media (MS) and alternative growing mediums (PDB, GAM, BAM and MCM). The media MS and PDB exhibited the highest growth rate $\left(0.02 \mathrm{~h}^{-1}\right)$, at 16 and $37^{\circ} \mathrm{C}$, respectively. Thirteen of the studied strains showed high capacity to produce DHA (up to $23 \%$ dry weight) and CT (up to $18 \%$ dry weight), comparable to levels observed in Schizochytrium sp. KH105 and Rhodosporidium toruloides. Additionally, all studied strains produce small amounts of EPA (up to $0.3 \%$ of dry weight). Scanning electron microscopy reveals that strain C36 is morphologically consistent with yeasts, while partial sequencing of the 18s ribosomal gene shows $97 \%$ similarity to the genus Rhodotorula, which has not been reported until now as a producer of DHA and EPA. Finally, the strains C36, C22 and C4 offer promising potential for upscaling their production for commercial use for enriching human food and animal and larval fish feed with omega-3 and carotenoids, as well as being a source for food dyes for salmon and other products.
\end{abstract}

Key words: Marine fungoid protist, DHA, EPA, total carotenoids, Rhodotorula, kinetic parameters

\section{INTRODUCTION}

The main commercial source of omega 3 long-chain polyunsaturated fatty acids (PUFA) is fish oil obtained through industrial-scale fisheries (Jackson \& Shepherd
2012). PUFAs are a major input in the production of feed for the fish farming industry. In the last two decades their cost has increase from US\$300 to US\$2300/ton owing to 
diminishing fishing catches because of overfishing and due to increased demand for PUFAs as nutritional supplements (Valenzuela et al. 2012).

As well, the temporal variability of fishery products, for example as a result of the events 'El Niño' and contamination by heavy metals, dioxins and polychloride biphenyls (PCBs) (Vicente et al. 2008) undermine the sustainability of fishery production. This has led to the search for new raw materials, such as oils from plants and microorganisms, to minimize the impact of fluctuations in the availability of marine resources.

In search for sustainable PUFA sources, marine microorganisms of the Thraustochytriaceae family have been isolated (Miller et al. 2007). The classic technique to isolate these microorganisms is the use of pine pollen as bait (Raghukumar \& Gaertner 1980). Through these techniques these types of microorganisms have been quantified in the world's oceans (Scheckenbach et al. 2010), indicating their importance in microbial carbon flows in marine environments (Raghukumar 2004).

The pollen bait technique has been used to isolate strains in the Humboldt Current System, with a collection of 129 strains, stored at the Marine Biotechnology Unit of the Universidad de Concepción that produce omega-3 polyunsaturated fatty acids (PUFAs), omega-3, docosahexanoic acid (DHA) and eicosapentanoic acid (EPA), and carotenoid pigments.

The objective of the present work was to identify and characterize marine fungoid strains in the collection that produce DHA, EPA and total carotenoids (CT). The optimal culturing conditions, substrate and temperature for the strains were determined in terms of production of the aforementioned substances. As well, the gene 18s rRNA was partially sequenced.

\section{Materials AND METHODS}

\section{Biological MATERIAL}

Forty-one strains of marine fungoid were used from the collection of the Marine Biotechnology Unit of the Universidad de Concepción, Chile. The strains were isolated from coastal waters of the Biobío and Carlos Ibáñez del Campo Regions (Fig. 1). All the strains were isolated from seawater according to the method of Gaertner (1966) for selective isolation of Thraustochytrids using pine pollen as bait. Isolation consists of observing by optical microscopic the adherence of marine fungoid to pine pollen in a liquid culture medium and transferring bait with positive adherence until obtaining a pure culture. The isolated clones were transferred to solid Sabouraud medium for storing and subsequent analysis.

\section{EXTRACTION OF POLYUNSATURATED FATTY ACIDS (PUFA)}

The strains were multiplied in solid Sabouraud medium to obtain sufficient material for PUFA analysis. Fatty acids were extracted from $100 \mathrm{mg}$ of biomass in the medium by saponification reaction with $1 \mathrm{~mL}$ de $\mathrm{NaOH}$ at $0.5 \mathrm{M}$ in $96 \%$ of ethanol and homogenized with Ultra Turrax for $1 \mathrm{~min}$. After cell rupture, the strains were centrifuged at $7000 \mathrm{x} \mathrm{g}$ for $5 \mathrm{~min}$. and the pellet discarded. One $\mathrm{mL}$ of $\mathrm{HCl}$ at $0.6 \mathrm{~N}$ and $3 \mathrm{~mL}$ of ethyl acetate were added to the supernatant, vortex agitated and incubated for $30 \mathrm{~min}$ at ambient temperature. The treated samples were dried by nitrogen current $\left(\mathrm{N}_{2(g)}\right)$ to eliminate the organic solvent, then lyophilized to eliminate remaining water and stored at $20^{\circ} \mathrm{C}$ for subsequent chromatographic analysis.

\section{Fatty ACID analysis}

Fatty acids were analyzed in a HPLC Hitachi (model L2000), using a UV detector (Hitachi, model L-2400), a gradient pump (Hitachi, model L-2100/2130) and a 15cm-X4.6-mm LC-18 Supelco® column. A gradient A with $25 \%$ of acetonitrile (ACN) and 75\% of Milli-Q purified water and a gradient $\mathrm{B}$ with pure $\mathrm{ACN}$ with $0.12 \%$ of acetic acid were used. The mobile phase used was $100 \%$ of A with a flow of $1 \mathrm{~mL} \mathrm{~min}^{-1}$ at $50 \%$ of B with a flow of $2 \mathrm{~mL} \mathrm{~min}^{-1}$ for $15 \mathrm{~min}$, followed by a flow at $1 \mathrm{~mL} \mathrm{m^{-1 }}$ for $30 \mathrm{~min}$. The samples were read at $195 \mathrm{~nm}$ and standards (Sigma-Aldrich ${ }^{\circledR}$ ) with an injection volume of $10 \mu \mathrm{L}$ to identify docosahexanoic and eicosapentanoic acids ( $\mathrm{Li}$ et al. 2001). Based on the results, the strains with the highest quantities of DHA and/ or EPA were selected.

\section{DETERMINATION OF TOTAL CAROTENOIDS}

Samples of $50 \mathrm{mg}$ in biomass were drawn from the strains under study; to which $1000 \mu \mathrm{L}$ of homogenized acetone was added with Ultra Turrax for $1 \mathrm{~min}$. Samples were then incubated for $10 \mathrm{~min}$ at $37^{\circ} \mathrm{C}$ and then centrifuged at 11,000 $\mathrm{x} \mathrm{g}$ for $10 \mathrm{~min}$. The supernatant was extracted for spectrophotometric analysis.

The extracts obtained were analyzed by the method described by Rodher (1966). A potassium dichromate calibration curve was made considering $0.036 \%$ of potassium dichromate equivalent to $0.0026 \% \mathrm{mg} \mathrm{mL}^{-1}$ of total carotenoids (TC). The analysis was carried out in $450-\mathrm{nm}$ glass cuvettes. 


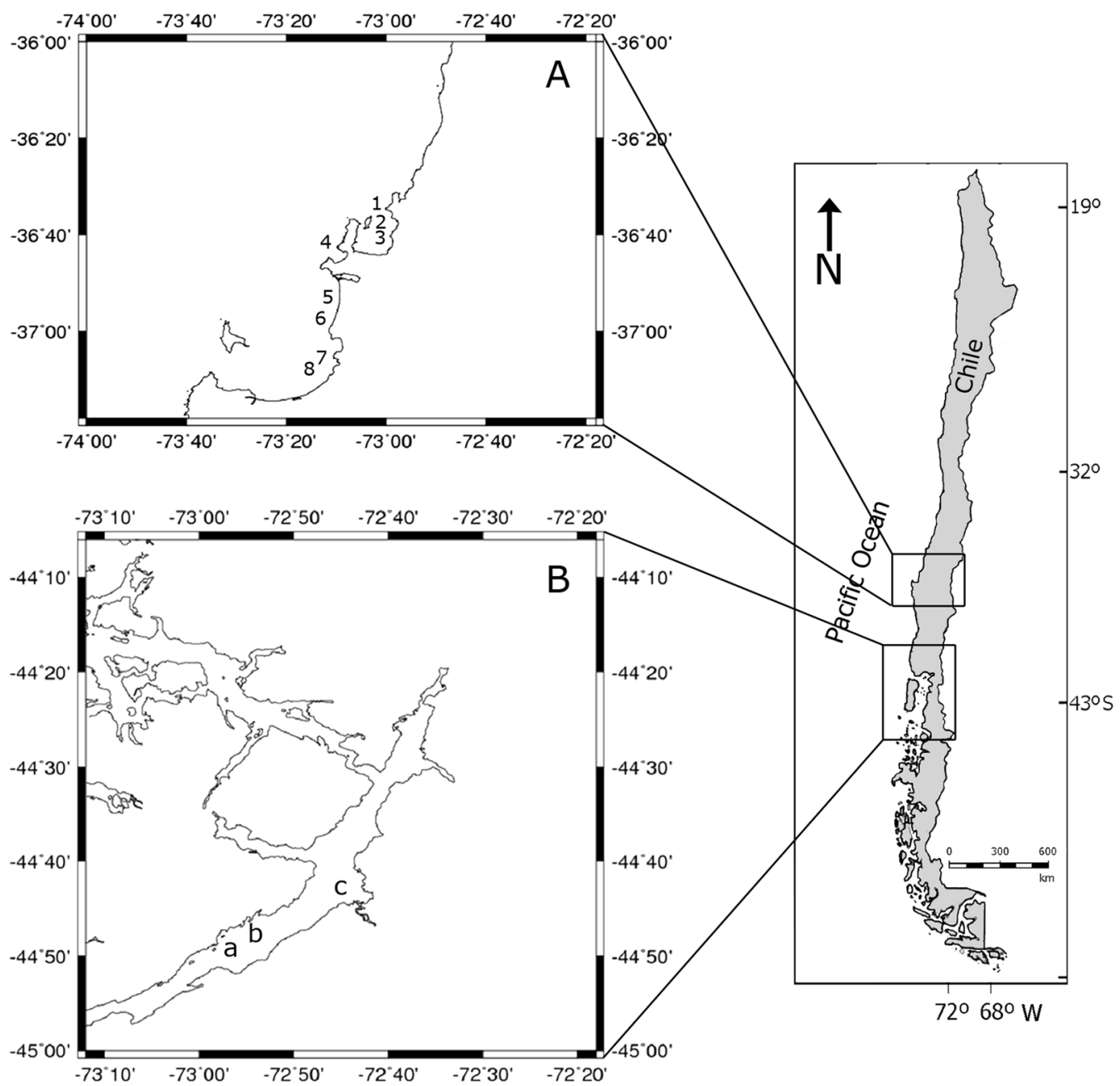

Figure 1. Geographic origin of the 41 strains of marine fungoid used in this study. A) Central Chile, Biobío Region: 1) Playa Dichato, 2) Playa Bellavista, 3) Playa Penco, 4) Playa Lenga 5) Caleta Maule, 6) Playa Blanca, 7) Playa Colcura and 8) Playa Laraquete. B) Austral-Southern Chile: sampling stations denominated a) E1, b) E18 and c) E22 in Canal Puyuhuapi; Carlos Ibáñez del Campo Region / Origen geográfico de las 41 cepas de fungoides marinos utilizadas en este estudio. A) Chile Central, Región del Biobío: 1) Playa Dichato, 2) Playa Bellavista, 3) Playa Penco, 4) Playa Lenga, 5) Caleta Maule, 6) Playa Blanca, 7) Playa Colcura y 8) Playa Laraquete. B) Chile Sur-Austral: estaciones de muestreo denominadas a) E1, b) E18 y c) E22, en el Canal Puyuhuapi, Región Carlos Ibáñez del Campo

PUFAs and total carotenoids were initially determined from the strains cultivated in solid media as a prequantification and pre-selection of potential producers of these substances. The selected strains were used in assays for quantification in liquid media.

\section{Culture media}

The biomass production of the selected strains was assessed in commercial and alternative liquid culture media at different temperatures. The media used were: green algae-based (GAM), brown algae-based (BAM),
Mazzaella laminaroides-based (MCM), Sabouraud (MS) and potato broth supplemented with dextrose (PDB). Before evaluating the cultures, $10-\mathrm{mL}$ of inoculum of each strain was developed and incubated in liquid glucose, yeast and peptone medium for 3 days at ambient temperature at $120 \mathrm{x} \mathrm{g}$. Each medium was evaluated at three temperatures: 16,25 and $37^{\circ} \mathrm{C}$ taking one $10 \mu \mathrm{L}$ of inoculum. These growths were cultured for 10 days at $120 \mathrm{x} g$ in $100-\mathrm{mL}$ flasks. 


\section{Preparation of Culture media}

\section{Algae based media}

Fronds of Ulva sp., Porphyra and Mazzaella laminaroides were collected for the green alga media (GAM), brown alga media (BAM) and Mazzaella laminaroides media (MCM), respectively. All the algae were obtained from rocky intertidal pools on the coast in the Biobío Region, Chile during low tide, taking care to avoid adhesion of epiphytes to the fronds. The fronds were stored and transported to the laboratory, where they were submerged in seawater to remove stones, sand and adhering epiphytes, with 2 or 3 repetitions of this step. The fronds were cooked in a pressure pot for 15 to $20 \mathrm{~min}$ in seawater sieved at $100 \mu \mathrm{m}$. The alga was then triturated and transferred to $100 \mathrm{~mL}$ Schott flasks sieved at a $100 \mu \mathrm{m}$, maintaining $\mathrm{pH}$ at 7 , and then autoclaved at $120^{\circ} \mathrm{C}$ for $15 \mathrm{~min}$.

\section{Sabouraud medium (MS)}

This medium $700 \mathrm{~mL}$ was prepared with commercial reactive formulated with dextrose in the following quantities: $21 \mathrm{~g}$ of dextrose, $7 \mathrm{~g}$ of peptone and $7 \mathrm{~g}$ of Instant Ocean sea salt at $\mathrm{pH}$ 7. The mixture was dissolved by mild agitation and then autoclaved at $120^{\circ} \mathrm{C}$ for $15 \mathrm{~min}$.

\section{Potato AND DEXTRose BRoth (PDB)}

To prepare $700 \mathrm{~mL}$ of the medium, $400 \mathrm{~g}$ of potato were weighed, cleaned thoroughly to avoid leaving all remaining earth and then cooked until completely soft, but without breaking. The broth was transferred to 1000 $\mathrm{mL}$ Schott flasks, $14 \mathrm{~g}$ of dextrose at $\mathrm{pH} 7$ was added and the mixture was autoclaved at $120^{\circ} \mathrm{C}$ for $15 \mathrm{~min}$.

Once all the media had been autoclaved and allowed to cool, $200 \mu \mathrm{L}$ of antibiotics were added $(1000 \mathrm{U} / \mathrm{mL}$ of penicillin and $1000 \mathrm{U} / \mathrm{mL}$ of streptomycin).

\section{Biomass PRODUCTION}

To determine biomass production cells were quantified with a hemocytometer from $10 \mu \mathrm{L}$ aliquots taken every 12 $\mathrm{h}$ from the culture media. The growth kinetics of the biomass or specific growth velocity (maximum $\mu$ ) was then determined according to the following formula:

$\mu \max \left(h^{-1}\right)=\frac{\Delta \text { biomass }}{\Delta \text { time }(h)}=\frac{\left(\operatorname{Ln} x-\operatorname{Ln} x_{0}\right)}{\Delta t}=\frac{\operatorname{Ln} 2}{t d}$

where, $x$ is biomass production reached in a determined time, $\Delta t$ is the cultivation time, and $x_{0}$ is initial biomass production.
Once cellular growth was completed, total biomass production in dry weight was determined. The samples were washed with distilled water, centrifuged at $3600 \mathrm{x} g$ for $20 \mathrm{~min}$ and lyophilized. The differences in production among the media were statistically analyzed with the Kruskal-Wallis test using XLSTAT2013 software.

\section{FATTY ACID AND TOTAL CAROTENOID PRODUCTION}

The levels of biomass productions of cultures in $100 \mathrm{~mL}$ flasks were determined in relation to the assessed culture media. Fatty acid and total carotenoid production were then determined in relation to the optimal growth conditions. The cultures were prepared in $500 \mathrm{~mL}$ matrices with agitation at $120 \mathrm{x} g$ for 10 days, taking $5 \mathrm{~mL}$ aliquots every $24 \mathrm{~h}$. The methodologies described above were followed to determine fatty acid and total carotenoid levels.

\section{MARINE FUNGOID IDENTIFICATION - DNA EXTRACTION}

The DNA of the marine basidiomycetes was extracted with the UltraClean ${ }^{\circledR}$ Microbial DNA Isolation Kit (MO BIO Laboratories Inc.) following the supplier's instructions. The extracted DNA was quantified with a NanoDrop $2000^{\circledast}$ spectrophotometer (ThermoScientific), as well as its purity was determined using 260/280 nm ratio, where $50 \mu \mathrm{g} \mathrm{mL}^{-1}$ was the conversion factor for DNA. Once purified and quantified, the DNA was stored at $-20^{\circ} \mathrm{C}$ until used.

\section{PCR AMPLIFICATION OF THE 18S RIBOSOMAL GENE}

A polymerase chain reaction (PCR) was used to amplify the $18 \mathrm{~s}$ rRNA gene. The primers used to identify the marine fungoid were $18 \mathrm{~S} 1$ and $18 \mathrm{~S} 12$ (Honda et al. 1999). The reaction mixture for the primers contained the following reactives: $5 \mathrm{X}$ buffer, $0,2 \mathrm{mM}$ of a mixture of dNTPs, $2 \mathrm{mM}$ of $\mathrm{MgCl}_{2}, 1 \mathrm{U}$ of Go-taq polymerase, $0.5 \mu \mathrm{M}$ of each primer and approximately $1.5 \mu \mathrm{L}$ de DNA in a final volume of 25 $\mu \mathrm{L}$. The amplification conditions were: initial denaturation at $95^{\circ} \mathrm{C}$ for $5 \mathrm{~min}$, followed by 35 amplification cycles. Each cycle consisted of denaturation at $95^{\circ} \mathrm{C}$ for $30 \mathrm{~s}$, alignment for $30 \mathrm{~s}$ at $55^{\circ} \mathrm{C}$ and extension at $72^{\circ} \mathrm{C}$ for $1 \mathrm{~min}$, with a final extension step of $72^{\circ} \mathrm{C}$ for $10 \mathrm{~min}$. The PCR products were visualized by electrophoresis in agarose gel at $2 \%$. The bands were visualized by gel staining with ethidium bromide $\left(0.5 \mu \mathrm{g} \mathrm{mL}^{-1}\right)$ and exposure with a UV transilluminator. 


\section{Purification, Cloning and extraction of Plasmids}

Having confirmed the expected size $(>1500 \mathrm{pb})$ of the bands by visualization, the bands were cut away from the gel and purified using the E.Z.N.A ${ }^{\circledR}$ Gel Purification Kit, following the supplier's instructions. The purified PCR product was ligated to the pGEM®T-Easy vector (Promega) using a vector ratio of $3: 1$ in a final reaction volume of $10 \mu \mathrm{L}$ and then incubated overnight at $4^{\circ} \mathrm{C}$.

Bacterial transformation was done with a vial of competent Escherichia coli cells (JM109® Promega) and the ligation product (recombinant plasmid), following the thermal shock methodology. The transformed bacteria were seeded in Petri dishes with LB agar and ampicillin $\left(50 \mu \mathrm{gmL}^{-1}\right)$, IPTG $(0.5 \mathrm{mM})$ and $\alpha$-galactosidase $(50 \mathrm{mg}$ $\mathrm{mL}^{-1}$ ), which allowed for identifying the bacteria in the recombinant plasmid. The seeded plates were left to grow overnight at $37^{\circ} \mathrm{C}$. The positive clones were confirmed by conventional PCR in colonies and the bands were viewed by ethidium bromide staining with and exposure in a UV transilluminator. The positive colonies were grown in liquid LB medium with ampicillin, and the DNA plasmid was purified with the commercial kit commercial Plasmid Miniprep kit II E.Z.N.A. ${ }^{\circledR}$, following the supplier's instructions

\section{Plasmid DNA sequencing and Phylogenetic MOLECULAR ANALYSIS}

The purified plasmids containing the cloned segment were sequenced by MACROGEN (South Korea). The sequences were used to identify the microorganisms by comparing them to sequences available in the GenBank Database $^{1}$. The BLAST program was used to search for the closest homologue sequences (Altschul et al. 1990) available at the NCBI website. The data was then processed with the MEGA 6 (Tamura et al. 2013) and Geneious version 6.0.3 programs (Drummond et al. 2011).

The sequences obtained from the studied strains were entered to the Genbank database with the following access numbers: KJ530974 (C6), KJ530975 (16CC1), KJ530976 (C36), KJ530977 (C3), KJ530978 (C30), KJ530979 (C46), KJ530980 (C51), KJ530981 (C24), KJ530982 (P39) and KJ530983 (C4).

\section{SCANNING ELECTRON MiCroscope}

The micrographs from the scanning electron microscope were taken at the Spectroscopy and Microscopy Center of the Universidad de Concepción with the following procedure: strain C36 was placed on a Peltier heating and cooling pad for $2 \mathrm{~h}$ at $35^{\circ} \mathrm{C}$ and then fixed with glutaraldehyde and osmium tetroxide, washed, dehydrated in a series of concentrations of acetone, including polymerized in resin. Finally, the preparations were cutted with an ultramicrotome. Subsequently the samples were covered with a $100 \AA$ A thick layers of platinum from an injecting apparatus and observed with a scanning electron microscope (Morris et al.1997).

\section{RESUlTS}

\section{IDENTIFICATION OF FATTY ACID AND CAROTENOID PRODUCING STRAINS}

Of the 41 strains of marine fungoid cultivated in solid media, the analysis for polyunsaturated fatty acids showed that 8 had high concentrations of DHA in the range of 0.5 to $5.6 \%$ of total dry weight biomass (Table 1).

Table 1. Concentration of docosahexaenoic acid (DHA) and total carotenoids (CT) in strains of marine fungoid isolated from different geographic areas grow $n$ in sabouraud solid media and selected as potential producers of these substances / Concentración de ácido docosahexanoico (DHA) y carotenoides totales (CT), en cepas de fungoides marinos aislados desde distintas áreas geográficas utilizando medio sólido sabouraud y seleccionados como potenciales productores de estas substancias

\begin{tabular}{cccc}
\hline Samples & Area & $\begin{array}{c}\text { \% DHA } \\
\text { in dry } \\
\text { weight }\end{array}$ & $\begin{array}{c}\text { \% CT } \\
\text { in dry } \\
\text { weight }\end{array}$ \\
\hline 16CC1 & Penco & Nd & 0.56 \\
C4 & Caleta Maule & 0.32 & 0.57 \\
P39 & PYPI-22-50m & Nd & 1.11 \\
C24 & Caleta Maule & 0.71 & 0.78 \\
C46 & Dichato & 0.55 & 0.87 \\
C51 & Dichato & Nd & 1.16 \\
C6 & Caleta Maule & 0.68 & $\mathrm{Nd}$ \\
C14 & Caleta Maule & 1.39 & $\mathrm{Nd}$ \\
C22 & Caleta Maule & 0.66 & $\mathrm{Nd}$ \\
C3 & Caleta Maule & 5.63 & $\mathrm{Nd}$ \\
C30 & Caleta Maule & 0.84 & $\mathrm{Nd}$ \\
O51 & Laraquete & 0.83 & 0.36 \\
C36 & Caleta Maule & $\mathrm{Nd}$ & 0.77 \\
\hline
\end{tabular}

Nd: not detectable

${ }^{1}$ National Center for Biotechnology Information, USA. NCBI. <http://www.ncbi.com> 
The total carotenoid analysis indicated that 7 strains had concentrations in the range of 0.5 to $1.1 \%$ of $\mathrm{CT}$ in dry weight (Table 1). Based on these results, the 13 strains considered in Table 1 were subsequently cultivated in liquid media. The other strains that presented production levels of less than $0.01 \%$ of DHA and $0.05 \%$ of total carotenoids were not considered further.

\section{OPTIMAL CULTURE CONDITIONS AND BIOMASS PRODUCTION IN LIQUID MEDIA}

Biomass production was low (Fig. 2) with the alternative alga-based culture media used in this study (GAM, BAM and MCM). Moreover, these media were not assayed with some strains until the end of the experiment (Fig. 3) because of the absence of any growth. The PDB medium was the only alternative media in which there was significant cellular growth $(P<0.05)$, reaching high cellular densities at $37^{\circ} \mathrm{C}$ (Figs. 2 and 3).

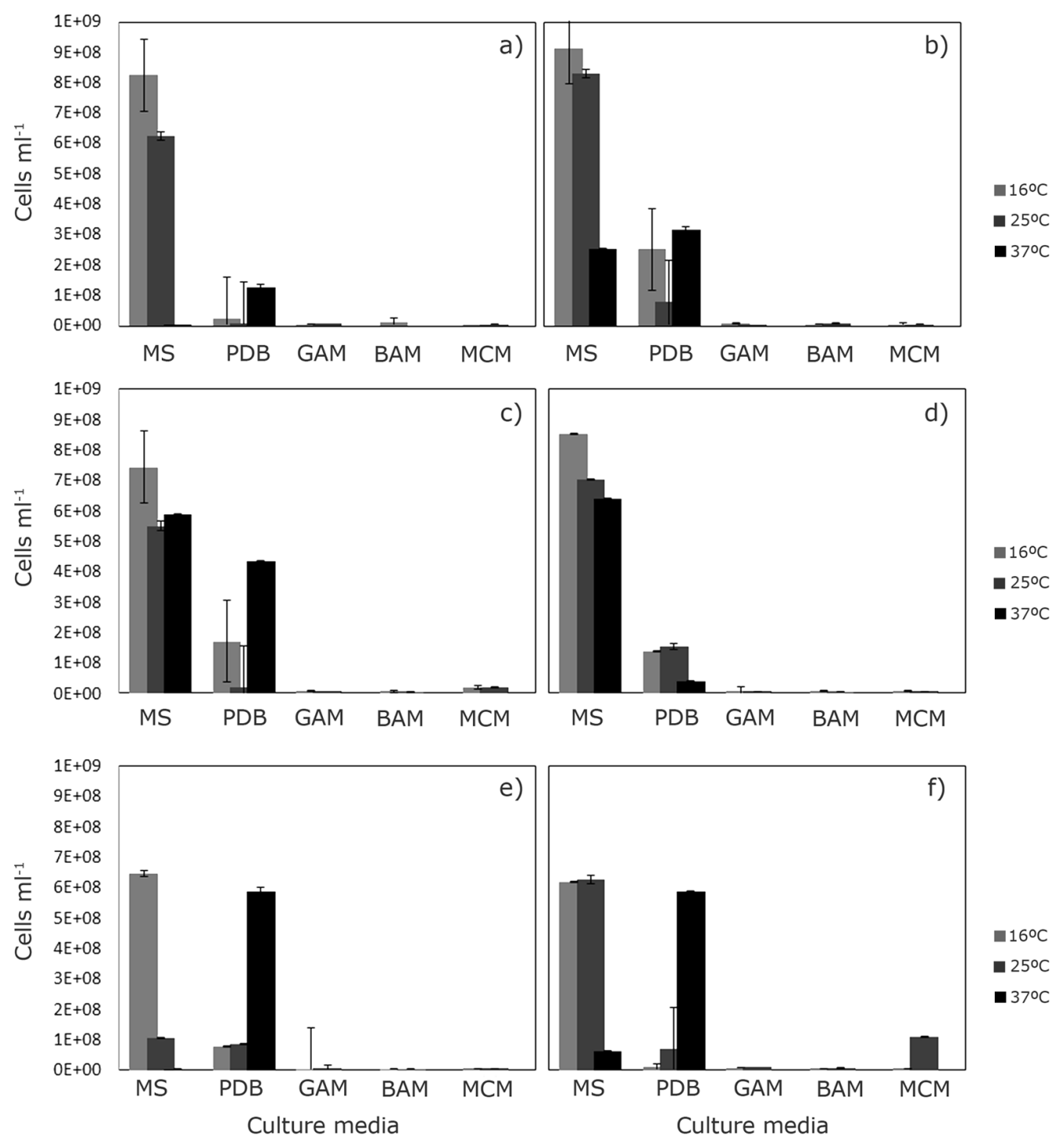

Figure 2. Maximum concentration of cells $\mathrm{mL}^{-1}$ in different culture media: Sabouraud medium (MS), potato broth supplemented with dextrose (PDB), green alga-based medium (GAM), brown alga-based medium (BAM) and M azzaella laminaroides-based medium (M CM), at 3 different temperatures. Strains evaluated: a) $16 \mathrm{CC1}$, b) C4, c) P39, d) C24, e) C46 and f) C51 / Concentración máxima de células $\mathrm{mL}^{-1}$, en diferentes medios de cultivo: Medio Sabouraud (MS), Caldo de papa suplementado con dextrosa (PDB), Medio a base de algas verdes (GAM), Medio a base de algas pardas (BAM) y Medio a base de Mazzaella laminaroides (MCM), a 3 diferentes temperaturas. Cepas evaluadas: a) $16 C C 1$, b) C4, c) P39, d) C24, e) C46 y f) C51 

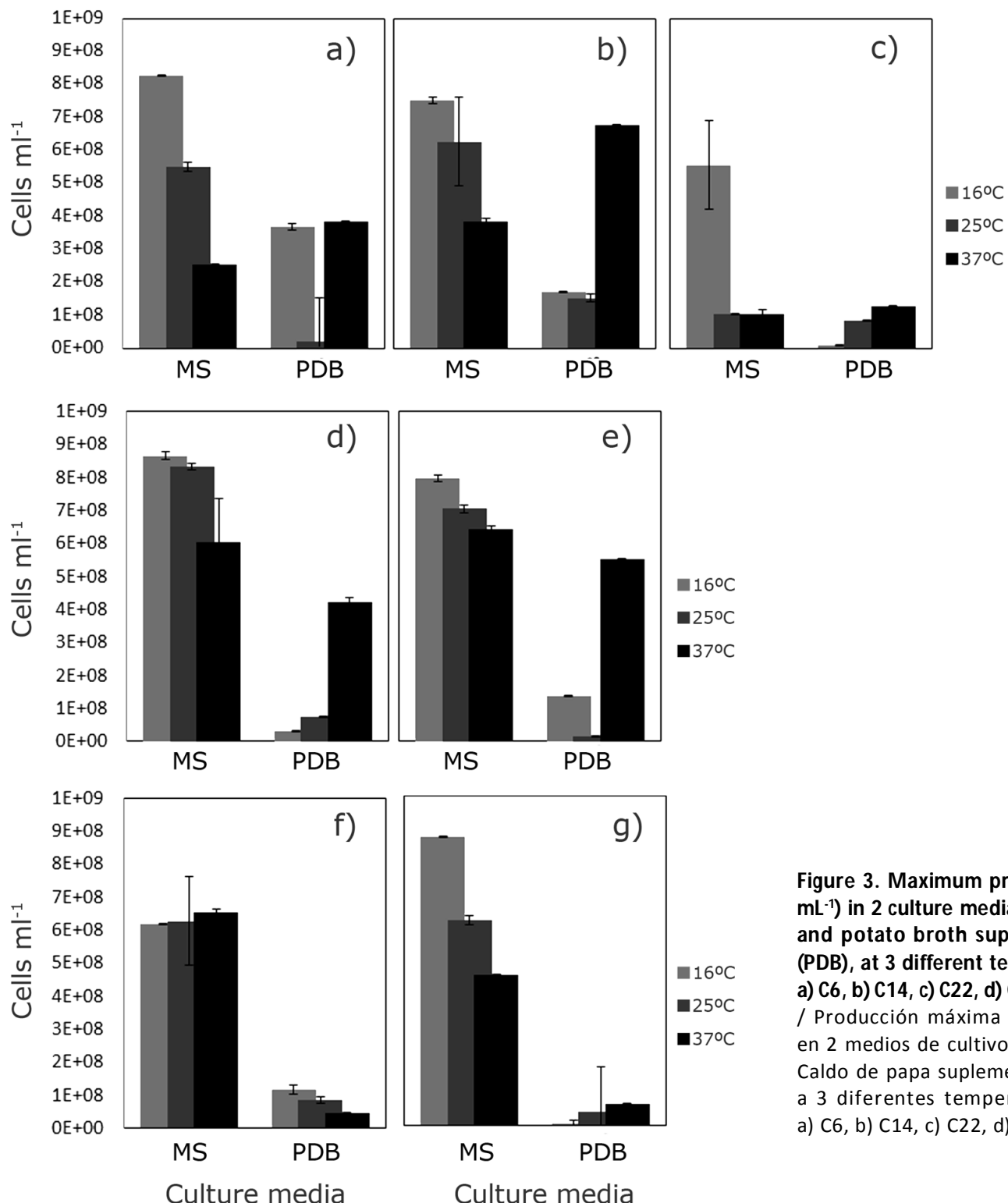

The highest level of biomass production $(P<0.05)$ in the liquid media assays was obtained at $16^{\circ} \mathrm{C}$ in Sabouraud liquid medium (MS), reaching cellular densities of $10^{8}$ to $10^{9}$ cells $\mathrm{mL}^{-1}$ (Figs. 2 and 3 ). The maximum growth velocities of the studied strains under the assay conditions were in the range of $0.02 \mathrm{~h}^{-1}$ to $0.03 \mathrm{~h}^{-1}$ with doubling times of 26 to $30 \mathrm{~h}$ (Table 2). Strain C4 (Fig. 2b) presented the highest total biomass production $(P<0.05)$, with a high maximum growth rate (Table 2).
Production of docosahexanoic (DHA) AND EICOSAPENTANOIC ACIDS (EPA) AND TOTAL CAROTENOIDS (CT) UNDER OPTIMAL LIQUID CULTURE CONDITIONS

The cultures of the 13 selected strains cultivated at $16^{\circ} \mathrm{C}$ in $500 \mathrm{~mL}$ of liquid $\mathrm{MS}$ medium presented a total dry biomass of 82 to $126 \mathrm{~g} \mathrm{~L}^{-1}$ of culture medium (Table 2). The dry biomass had a content of 1.1 to $23 \%$ of DHA, 0.03 to $0.1 \%$ of EPA and 4 to $18 \%$ of CT (Table 2). 
Table 2. Production of eicosapentanoic acid (EPA), docosahexanoic acid (DHA) and total carotenoids (CT), of the 13 selected strains grown at $16^{\circ} \mathrm{C}$, Sabouraud liquid medium in bioreactors in batches of $500 \mathrm{~mL}$. Results are expressed as concentrations of the substances in $\mathbf{g}$ of dry weight of biomass and the percentage in $\mathbf{g}$ of such biomass. Maximum growth rates ( $\mu$ max), grown in liquid Sabouraud medium at $16^{\circ} \mathrm{C} /$ Producción de ácido eicosapentanoico (EPA), ácido docosahexanoico (DHA) y carotenoides totales (CT), de las 13 cepas seleccionadas y cultivadas a $16^{\circ} \mathrm{C}$, medio líquido Sabouraud en biorreactores en batch de $500 \mathrm{~mL}$. Los resultados se expresan como concentración de las substancias por g de biomasa seca y su porcentaje en gramos para dicha biomasa. Tasas de crecimiento máxima ( $\mu$ max), cultivadas en Medio líquido Sabouraud a $16^{\circ} \mathrm{C}$

\begin{tabular}{|c|c|c|c|c|c|c|c|c|c|c|c|c|c|}
\hline & \multicolumn{13}{|c|}{ Strains } \\
\hline & $\mathrm{C} 24$ & $\mathrm{C} 46$ & C6 & C14 & $\mathrm{C} 22$ & $\mathrm{C} 3$ & $\mathrm{C} 30$ & O51 & $\mathrm{C} 4$ & P39 & C51 & $16 \mathrm{CC} 1$ & $\mathrm{C} 36$ \\
\hline \multicolumn{14}{|l|}{ Total production ( $500-\mathrm{mL}$ bioreactor) } \\
\hline EPA (mg EPA g ${ }^{-1}$ biomass) & 0.3 & 1.5 & 0.4 & 0.7 & 2.5 & 0.3 & 0.4 & 1 & 1 & 0.3 & 0.4 & 0.4 & 2 \\
\hline DHA (mg DHA $\left.\mathrm{g}^{-1}\right)$ biomass & 180 & 136 & 27 & 53 & 234 & 136 & 62 & 170 & 98 & 40 & 27 & 11 & 234 \\
\hline CT (mg total C. $\mathrm{g}^{-1}$ biomass) & 59 & 101 & 83 & 59 & 123 & 59 & 125 & 59 & 179 & 41 & 45 & 134 & 106 \\
\hline$\%$ EPA in biomass in dry weight & 0.03 & 0.1 & 0.04 & 0.07 & 0.3 & 0.03 & 0.04 & 0.1 & 0.1 & 0.03 & 0.04 & 0.04 & 0.2 \\
\hline$\%$ DHA in biomass in dry weight & 18 & 14 & 3 & 5 & 23 & 14 & 6 & 17 & 10 & 4 & 3 & 1.1 & 23 \\
\hline$\% \mathrm{CT}$ in biomass in dry weight & 6 & 10 & 8 & 6 & 12 & 6 & 12 & 6 & 18 & 4 & 5 & 13 & 11 \\
\hline Biomass in dry weight $\left(\mathrm{g} \mathrm{L}^{-1}\right)$ & 9.6 & 9.2 & 12.2 & 10.6 & 12.6 & 11.8 & 9.8 & 9.0 & 9.4 & 12.2 & 9.2 & 10.6 & 8.2 \\
\hline \multicolumn{14}{|l|}{ Growth parameters } \\
\hline Maximum $\mu\left(\mathrm{h}^{-1}\right)$ & 0.02 & 0.02 & 0.02 & 0.02 & 0.02 & 0.02 & 0.02 & 0.02 & 0.03 & 0.02 & 0.03 & 0.02 & 0.03 \\
\hline
\end{tabular}

Strains C36 and C22 produce DHA in up to $23 \%$ of dry weight, which is significantly higher $(P<0.05)$ than the levels produced by the other strains (Table 2). Strain $\mathrm{C} 4$ produced the highest levels of CT $(P<0.05)$, reaching $18 \%$ of dry weight (Table 2 ). The 13 cultivated strains can produce eicosapentanoic acid (EPA), although in lower concentrations than the DHA produced (Table 2).

\section{Molecular Characterization OF THE THIRTEen MARINE FUNGOID STRAINS SELECTED AS HIGHLY PRODUCTIVE OF DHA AND CT}

The selected 13 strains were positively amplified by conventional PCR with the primers described by Honda et al. (1999). This fragment was sequenced with an amplicon of $1500 \mathrm{pb}$.

The BLAST analysis of all the sequenced strains from the coasts of the Biobío and Carlos Ibáñez del Campo Regions had 91 to $97 \%$ genetic similarity to Rhodotorula and Rhodosporidium. They also shared $81 \%$ similarity with species of the Thraustochytriceae, thus ruling out that the strains are Thraustochytrids due to the low percentage of similarity to this family. Two clusters were observed in the phylogenetic tree (Fig. 4) of the sequenced strains and sequenced microorganisms of the aforementioned family. The strains C36, C24, C22, C3 and
$\mathrm{C} 30$ are $97 \%$ related to Rhodotorula sp. and Rhodosporidium diobovatum, forming a robust cluster. The strains C6, 16CC1, C14, P39, C51, C46, C4 and O51 form another cluster related with $91 \%$ to Rhodotorula and Rhodosporidium and $81 \%$ similarity to the Thraustochytriceae family. The strains C3-C30 and C22$\mathrm{C} 24$ are similar to each other, as are the strains C6-16CC1C4. Both clusters are different from Schizochytrium sp. and Prorocentrum micans, the latter used as a reference.

\section{Characterization of strain C36 by scanning ELECTRON MICROSCOPE}

Given the similarity of the molecular information for genera Rhodotorula and Rhodosporidium, scanning electron micrographs were obtained of the strain C36 cultivated in Sabouraud and Vishniac media (Vishniac 1956). The micrographs of the cultures in Sabouraud medium show cells approximately 3 to $5 \mu \mathrm{m}$ in size, with a morphology like that of yeast, including some are in gemmation (Fig. 5a). The micrographs of cultures in Vishniac medium also show cells with yeast-like morphology and slightly larger than those in Sabouraud medium. An ectoplasmic network similar to that described for the Thraustochytride group can also be observed (Fig. $5 b)$. 


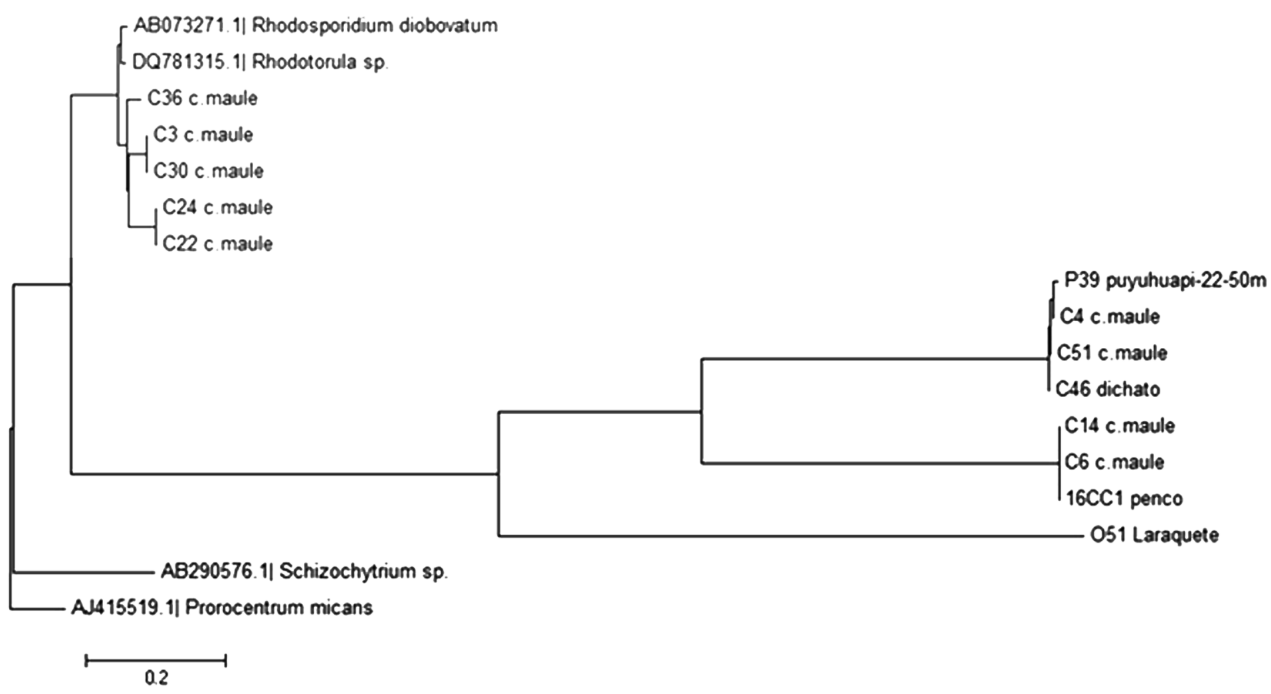

Figure 4. Phylogenetic tree of the partial sequence of 18S RNA gen of the 13 marine fungoid strains selected and isolated from the coast of the Biobío Region (C. Maule, Dichato, Laraquete and Penco) and Carlos Ibáñez del Campo (Canal Puyuhuapi, E22). The following species were used for comparisons: Rhodotorula sp., Rhodosporodium diobovatum and Schizochytrium sp., which represent the gender Rhodotorula, Rhodosporidium and family Thraustochytriaceae, respectively. Prorocentrum micans, was used as out group. The tree was constructed using the neighbor-joining method (NJ) and MEGA program 6 / Árbol filogenético basado en la secuencia parcial del gen 18S RNA de fungoides marinos obtenidos desde las costas de la Región del Biobío (C. Maule, Dichato, Laraquete y Penco) y Carlos Ibáñez del Campo (Canal Puyuhuapi, E22). Para comparar se utilizaron las especies Rhodotorula sp., Rhodosporodium diobovatum y Schizochytrium sp., representantes de los géneros Rhodotorula, Rhodosporidium y familia Thraustochytriaceae, respectivamente. Prorocentrum micans, fue utilizada como outgroup. El árbol fue construido mediante el método de Neighbor-joining (NJ) y programa MEGA 6
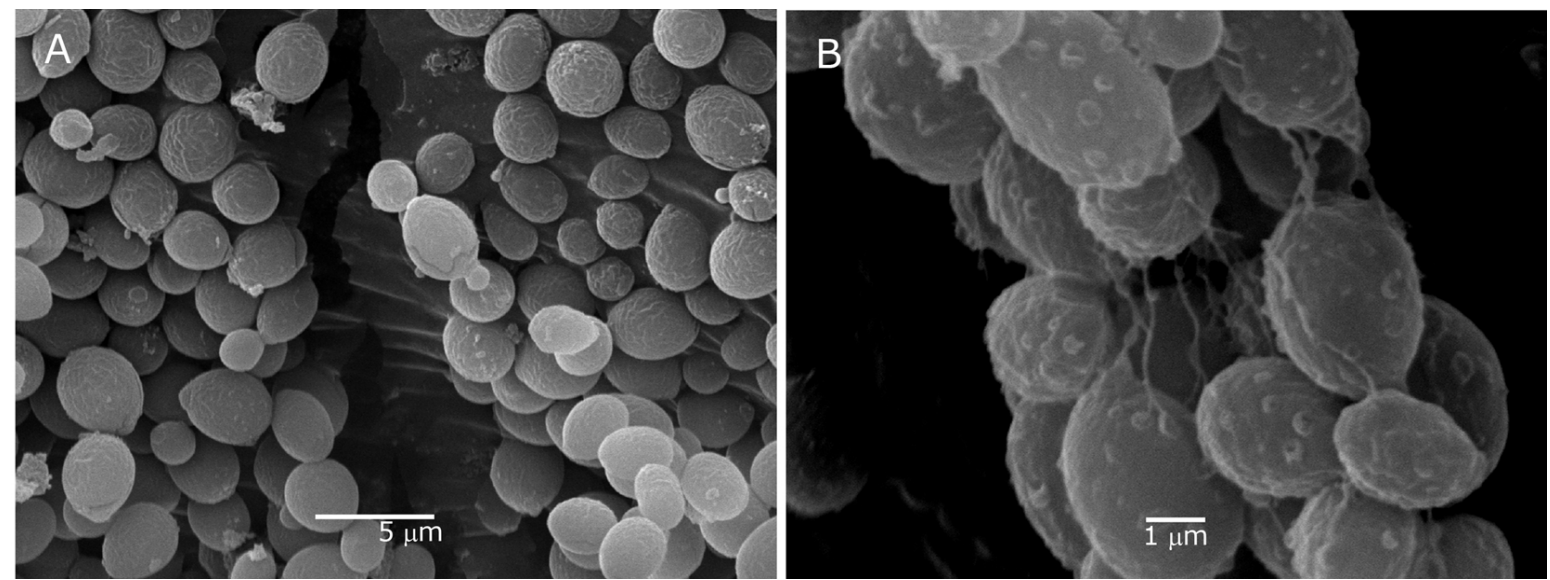

Figure 5. Scanning electron micrographs of strain C36. A) yeast-like cell structures approximately 3 to $5 \mu \mathrm{m}$ long. Gems or sterigmata and B) ovoid cellular structures linked by an ectoplasmic-like net can be observed. Approximately 4-6 $\mu \mathrm{m}$ long / Micrografías electrónicas de barrido de la cepa C36. A) estructuras celulares levaduriformes de aproximadamente 3 a $5 \mu \mathrm{m}$ de largo, con presencia de gemas o esterigmas y $B$ ) estructuras celulares ovoidales con presencia de una red superficial similar a una red ectoplasmática. Tamaño aproximado de 4 a $6 \mu \mathrm{m}$ de largo 


\section{Discussion}

The pine pollen bait technique (Gaertner 1966) consists of directly isolating microorganisms from seawater that can be grown on pine pollen and that have morphology consistent with that of the Thraustochytrids group widely described through this technique (Bongiorni 2012). This technique was chosen because the microorganisms isolated with it are potential producers of substances of commercial interest such as DHA, EPA and carotenoids (Yamasaki et al. 2006) and allowed for constructing the strain collection used to investigate the presence of such substances. The results obtained from the solid media (SM) of the microorganisms of this collection show the existence of 13 DHA and CT producing strains from the Biobío and Carlos Ibáñez del Campo Regions. Eight of these strains produce DHA and 6 produce CT, varying in color from fuchsia (magenta), pink to orange, a characteristic of PUFA and carotenoids-producing marine fungoid (Pemán et al. 2007). Marine fungoid present high omega-3 PUFA concentrations and several strains can accumulate lipids up to $70 \%$ (Ratledge \& Wynn 2002, Li et al. 2007). Species of the genera Rhodotorula and Rhodosporidium produce carotenoids at commercially interesting levels, with colonies that present reddishorange and fuchsia coloring, which are similar to the colors of the studied strains. The intensity of the coloring varies depending on the strain owing to the presence of pigments such as astaxanthin (Andrews et al. 1976). However, these species have been isolated from terrestrial ecosystems and consequently no marine species has been described as highly productive of lipids or carotenoids. In the case of the Thraustochytriidae, high levels of PUFA production, such as DHA, have been observed, reaching $26 \%$ of dry weight biomass (Yamasaki et al. 2006). This establishes them as potentially sustainable and commercially important alternative for PUFA production, as are the strains studied in this work.

Given the biotechnological interest in these marine fungoid, it is necessary to optimize biomass production to obtain substances of commercial interest that they synthesize (DHA, EPA and CT). In this context, identifying liquid culture media alternative to commercial media could reduce production costs of these microorganisms for their upscaling to the industrial level (Quilodrán et al. 2010). The highest level of biomass production reached in this study was with Sabouraud liquid media (MS) at $16^{\circ} \mathrm{C}$. The biomass production of the medium of potato broth supplemented with dextrose (PDB), at $37^{\circ} \mathrm{C}$ was similar to that of $\mathrm{MS}$ at $25^{\circ} \mathrm{C}$, which suggests that starchy substrates are an alternative for cultivating the studied strains using the waste from other productive activities involving starch. Growth levels in marine alga-based media were low compared to levels in PDB and MS. The strain C51 in Mazzaella laminaroides-based medium (MCM) at $25^{\circ} \mathrm{C}$ yielded $10^{8}$ cells $\mathrm{mL}^{-1}$, similar to the levels obtained in $\mathrm{MS}$ and $\mathrm{PDB}$ at 16 and $37^{\circ} \mathrm{C}$, respectively. The limited growth in alga-based media (MCM, GAM and BAM) was probably the result of a substance in the media like polysaccharides of the alga or phenols that are enzymatic inhibitors (Ríos et al. 2009). The use of disaccharides or polysaccharides as carbon sources for some marine fungoid results in low growth levels, although other fungoid can grow with cellobiose, maltose and soluble starch (Goldstein 1963a, b). Several authors have also reported the use of alternative media for growing marine fungoid (Quilodrán et al. 2010). The use of substrates based on residues from industrial processes is a viable alternative for the mass production of microorganisms. Based on the resulted of the present work, it is necessary to improve the composition of alternative media (MCM, GAM, BAM and PDB), incorporating determined quantities of micronutrients such as iron, zinc, magnesium and vitamins, among others, as these are essential for the growth of eukaryotes and optimizing marine fungoid production (Cartagena et al. 2013).

Growth kinetics parameters are important variables in selecting the optimal biomass production conditions (Ertola et al. 1994). The use of the parameter maximum growth velocity in the present work allowed for discriminating among the formulated media (Table 2). Generally, the growth curves obtained for the assayed strains in Sabouraud media reached maximum growth velocities between 0.02 and $0.03 \mathrm{~h}^{-1}$ with concentrations of $10^{8}$ to $10^{9}$ cells $\mathrm{mL}^{-1}$. The cellular concentrations reached by the strains in the present study are approximately on the same order of magnitude as those reported in studies of Rhodotorula and Rhodosporidium (Martearena et al. 2009, Martínez 2012). The 13 strains studied here present maximum production levels of up to $8.5 \times 10^{8}$ cells $\mathrm{mL}^{-1}$, with the exception of strain $\mathrm{C} 4$, which reached $1.5 \times 10^{9}$ cells $\mathrm{mL}^{-1}$. These cellular densities are similar to those reached by Rhodotorula mucilaginosa, which are on the order of $1.3 \times 10^{6}$ to $1.8 \times 10^{8}$ cells $\mathrm{mL}^{-1}$ (Martearena et al. 2009, Martínez 2012).

The 13 marine fungoid strains cultivated in $\mathrm{MS}$ at $16^{\circ} \mathrm{C}$ in $500 \mathrm{~mL}$ bioreactors de $500 \mathrm{~mL}$ produced between 1.1 and $23 \%$ of DHA in dry weight. The strains C36 and C22 
for their high DHA concentrations, which were higher than what is described in the literature (Bajpai et al. 1991, Burja et al. 2006, Yamasaki et al. 2006, Chi et al. 2007). Rhodosporidium toruloides and Rhodotorula glutinis produce around 70 and $33.7 \%$ of total lipids in dry weight, respectively. However, the fatty acids produced by these species include myristic, palmitic, palmitoleic, steric, oleic, linoleic and $\alpha$-linoleic acids (Li et al. 2006, Freitas et al. 2014), in contrast to the strains studied here that produce high concentrations of DHA and EPA, neither of which have been described in Rhodotorula and Rhodosporidium (Li et al. 2007, Hu et al. 2009).

Other marine fungoid protist like Thraustochytrids are also potentially important alternatives to fish oil, with levels of DHA production similar to those of the strains studied here, with DHA concentrations of $26 \%$ in dry weight for Schizochytrium limacinum (Yaguchi et al. 1997). This microorganism, unlike the strains in this study, comes from a warm ecosystem. The strain Thraustochytriidae sp. AS4-A1 (Quilodrán et al. 2010), which was isolated in southern Chile, presents DHA concentrations of between 0.1 and $14 \%$ in dry weight, has been cultivated with alternative media composed of commercial residues from producing potato chips and beer. However, Thraustochytriidae sp. AS4-A1 produces less DHA than the levels determined for the strains C24, C46, C22, C3, O51 and C36 from the present study. The 13 marine fungoid also produce EPA ( 0.3 to $0.03 \%$ of biomass in dry weight), while Thraustochytriidae sp. AS4-A1 does not (Quilodrán et al. 2010). The production of this PUFA makes the studied strains even more interesting, presenting the advantage of offering 2 polyunsaturated fatty acids of commercial importance, making them comparable to already described species of Thraustochytrids; Ulkenia sp. KF13, $T$. striatum KF9, S. mangrovei KF5 and Schizochytrium sp. $\mathrm{KF}$ 1, which yield concentrations of 1.4, 8.6, 7 and $12.5 \%$ of dry weight, respectively (Fan et al. 2001).

The total carotenoid production of the cultivated strains (41 to $179 \mathrm{mg} \mathrm{CT} \mathrm{g}^{-1}$ of biomass in dry weight) is higher than that described for Rhodotorula mucilaginosa and Rhodotorula glutinis (21.4 and 35 $\mathrm{mg} \mathrm{CT} \mathrm{g}^{-1}$ of biomass in dry weight, respectively), both considered highly productive of carotenoids (Aksu \& Eren 2005, Saenge et al. 2011). The strains reported in the present work can potentially be used to produce natural pigments that are currently in high demand by the aquaculture industry (Aki et al. 2003, Wassef et al. 2010).
The molecular characterization of the 13 studied strains shows consistency between the sizes of the PCR products and those described by Honda et al. (1999), and Yokoyama et al. (2007). The primers used by Honda et al. (1999) are characterized as well for presenting specificity with marine fungoid given that they do not amplify for Saccharomyces cerevisiae (Socias 2012).

The molecular systematization of this group of marine fungoid isolated from marine ecosystems of central and southern Chile established their genetic similarity to strains described in the Genbank database, characterized by their lipid and carotenoid producing capacity. The closest species genetically to those studied in this work are Rhodotorula and Rhodosporidium (97\%), both characterized as lipid and carotenoid producers (Saenge et al. 2011, Freitas et al. 2014). A more distant similarity $(81 \%)$ was found with species of the Thraustochytriaceae family, characterized by high levels of DHA production (Chi et al. 2007). The strains C22, C24, C30, C3 and C36 share the same cluster with Rhodotorula sp. and Rhodosporidium diobovatum, in the phylogenetic tree, the strains in the present study being highly productive of DHA as a common biochemical characteristic among them. Although the other cluster observed are associated with production of substances of interest, more study is required to correlate the partial sequence of the gene $18 \mathrm{~s}$ rRNA to the productive attributes discussed here.

The phylogenetic information obtained in the present work shows that the strains isolated from Canal Puyuhuapi are genetically similar to microorganisms isolated from the coast of the Biobío Region, indicating that these microorganisms are widely distributed latitudinal along the coast and fjord systems of central and southern Chile. The wide distribution of the marine fungoid studied here is consistent with what was described by Bongiorni et al. (2004, 2012).

A high degree of similarity to the family Thraustochytriceae was expected given that the strains were isolated using the pollen bait technique used for Thraustochytrides. However, only $81 \%$ genetic similarity to Schizochytrium sp. was obtained, a lower percentage than for the genera Rhodotorula and Rhodosporidium, which are good candidates for classifying the 13 strains. This information indicates that the studied strains belong to the genus Rhodotorula or Rhodosporidium. The genera Rhodotorula and Rhodosporidium are characterized by their ovoid shape, with vegetative states that are reproduced predominantly by gemmation or fission. They 
are classified in the taxonomic division Eumycota, belonging to the subdivision Basidiomicotin, which are characterized by external spores located on basidia or sterigmata (Ochoa \& Juárez 2004). Microscopic information obtained for strain $\mathrm{C} 36$, characterized in the present study as being highly productive of DHA and CT, are morphologically similar Rhodotorula glutinis and Rhodosporidium diobovatum (Ochoa \& Juárez 2004). Ovoid-shaped cells were observed in the micrographs, in some of which gemmae are forming. A surface network was also observed covering cells similar to those in Thraustochytrids termed an ectoplasmic network (Perkins 1972). The information obtained here raises the question of whether microorganisms quantified and isolated through the pollen bait technique are all Thraustochytrides or whether they belong to other uncharacterized fungoid protist families (Bongiorni 2012).

In conclusion, the present study shows that strains from central and southern Chile are a potential source of DHA, EPA and carotenoids, highlighting the strains C36, $\mathrm{C} 22$ and $\mathrm{C} 4$ as producers of these substances under optimal growth conditions in liquid media.

Strain C36 is morphologically and genetically similar to Rhodotorula, which are terrestrial lipid and carotenoid producers, but there is no record indicating that the lipids produced are associated with DHA and EPA (Martínez 2012). Finally, this strain of marine origin may be the best option to upscale production at the level of a prototype and subsequent use commercially.

\section{ACKNOWLEDGMENTS}

This work was financed by the Programa Copas SurAustral (PFB-31). We acknowledge to Unit of Marine Biotechnology and Laboratory of Marine Geochemistry of the Universidad de Concepción. Finally, like to thank to $\mathrm{PhD}$. Fernando Cruzat for their assistance in the bioinformatics work.

\section{LITERATURE CITED}

Aki T, K Hachida, M Yoshinaga, Y Katai, T Yamasaki, S Kawamoto, T Kakizono, T Maoka, S Shigeta, O Suzuki \& K Ono. 2003. Thraustochytrid as a potential source of carotenoids. Journal of the American Oil Chemists' Society 80: 789-794.

Aksu Z \& TA Eren. 2005. Carotenoids production by the yeast Rhodotorula mucilaginosa: Use of agricultural wastes as a carbon source. Process Biochemistry 40(9): 2985-2991.
Andrews AG, HJ Phaff \& MP Starr. 1976. Carotenoids of Phaffia rhodozyma, a red pigmented fermenting yeast. Phytochemistry 15: 10003-10007.

Bajpai P, P Bajpai \& OP Ward. 1991. Optimization of production of docosahexaenoic acid (DHA) by Thraustochytrium aureum ATCC 34304. Journal of the American Oil Chemists' Society 68: 509-514.

Bongiorni L. 2012. Thraustochytrids, a neglected component of organic matter decomposition and food webs in marine sediments. Biology of Marine Fungi 53(1): 1-13.

Bongiorni L, L Pignataro \& G Santangelo. 2004. Thraustochytrids (fungoid protist): an unexplored component of marine sediment microbiota. Scientia Marina 68(S1): 43-48.

Burja AM, H Radianingtyas, A Windust \& CL Barrow. 2006. Isolation and characterization of polyunsaturated fatty acid producing Thraustochytrium species: screening of strains and optimization of omega-3 production. Applied Microbiology and Biotechnology 72: 1161-1169.

Cartagena EG, LY Britto, LJ Rodríguez \& CL Zapata. 2013. Efecto de la Zeolita natural clinoptilita sobre el crecimiento de Dunaliella salina (teodoresco, 1905) cultivada en un fotobiorreactor de múltiples cámaras oscilantes. BIOCYT: Biología Ciencia y Tecnología 6: 20-24.

Chi Z, D Pyle, Z Wen, C Frear\& S Chen. 2007. A laboratory study of producing docosahexaenoic acid from biodieselwaste glycerolby microalgal fermentation. Process Biochemistry 42: 1537-1545.

Drummond A, B Ashton, S Buxton, M Cheung, A Cooper, C Duran, M Field, J Heled, M Kearse, S Markowitz, R Moir, S Stones-Havas, S Sturrock, T Thierer \& A Wilson. 2011. Geneious Basic: an integrated and extendable desktop software platform for the organization and analysis of sequence data. Bioinformatics 28(12): 1647-1649.

Ertola R, O Yantorno \& C Mignone. 1994. Microbiología industrial, 104 pp. OEA, Washington.

Fan KW, F Chen, EB Jones \& LL Vrijmoed. 2001. Eicosapentaenoic and docosahexaenoic acids production by and okara-utilizing potential of thraustochytrids. Industrial Microbiology and Biotechnology 27: 199-202.

Freitas C, TM Parreira, J Roseiro, A Reis \& TL da Silva. 2014. Selecting low-cost carbon sources for carotenoid and lipid production by the pink yeast Rhodosporidium toruloides NCYC 921 using flow cytometry. Bioresource Technology 158: 355-359.

Gaertner A. 1966. Vorkommen, physiologie und verteilung, mariner niedererpilze (Aquatic Phycomycetes). Veröffentlichungen des Instituts für Meeresforschung in Bremerhaven (Suppl.) 2: 221-236.

Goldstein S. 1963a. Development and nutrition of a new species of Thraustochytrium. American Journal of Botany 50: 799-811. 
Goldstein S. 1963b. Studies of a new species of Thraustochytrium that displays light stimulated growth. Mycologia 55: 799-811.

Jackson AJ \& CJ Shepherd. 2012. The future of fishmeal and fish oil. In: Ryder J, L Ababouch \& M Balaban (eds). Second international congress on szeafood technology on sustainable, innovative and healthy seafood, FAO/The University of Alaska, 10-13 May 2010, Anchorage. FAO Fisheries and Aquaculture Proceedings 22: 187-206. FAO, Rome.

Honda D, T Yokochi, T Nakahara, S Raghukumar, A Nakagiri, K Schaumann \& T Higashihara. 1999. Molecular phylogeny of labyrinthulids and thraustochytrids based on the sequencing of $18 \mathrm{~S}$ ribosomal RNA gene. Journal of Eukaryotic Microbiology 46: 637-647.

Hu C, X Zhao, J Zhao, S Wu \& ZK Zhao. 2009. Effects of biomass hydrolysis by-products on oleaginous yeast Rhodosporidium toruloides. Bioresource Technology 100(20): 4843-4847.

Li Z, T Gu, B Kelder \& J Kopchick. 2001. Analysis of fatty acids in mouse cells using reversed- phase high-performance liquid. Chromatographia 54: 463-467.

Li YH, BO Liu, ZB Zhao \& FW Bai. 2006. Optimization of culture conditions for lipid Production by Rhodosporidium toruloides. Chinese Journal of Biotechnology 22(4): 650656.

Li YH, ZB Zhao \& FW Bai. 2007. High-density cultivation of oleaginous yeast Rhodosporidium toruloides $\mathrm{Y} 4$ in fed-batch culture. Enzyme and Microbial Technology 41: 312-317.

Martearena MR, E Scaroni \& S Locatelli. 2009. Producción de lípidos a partir de levadura oleaginosa Rhodotorula glutinis. Segundo Congreso Iberoamericano, Hidrogeno y Fuentes Sustentables de Energía, HYFUSEN, Córdoba, Argentina, pp. 12-73.

Martínez R. 2012. Producción de lípidos por cepas de Chlorella pyrenoidosa y Rhodotorula mucilaginosa y generación de un consorcio microbiano. Doctoral dissertation, Universidad Autónoma de Nuevo León, Nuevo León, 111 pp.

Miller M, P Nichols \& C Carter. 2007. Replacement of fish oil with thraustochytrid Schizochytrium sp. L oil in Atlantic salmon parr (Salmo salar L) diets. Comparative Biochemistry and Physiology 148: 382-392.

Morris CE, JM Monier \& J Marie-Agne. 1997. Methods for observing microbial biofilms directly on leaf surfaces and recovering them for isolation of culturable microorganisms. Applied and Environmental Microbiology 63: $1570-1576$.

Ochoa JL \& RV Juárez. 2004. Las levaduras marinas como herramienta científica y biotecnológica, $12 \mathrm{pp}$. Red Universidad y Ciencia, La Paz.
Pemán J, E Martín-Mazuelos \& MC Rubio-Calvo. 2007. Guía práctica de Identificación y diagnóstico en micología clínica. Identificación de levaduras. Revista Iberoamericana de Micología de Bilbao 11: 143-155.

Perkins FO. 1972. The ultrastructure of holdfasts, 'rhizoids', and slime tracks in thraustochytriaceous fungi and Labyrinthula spp. Archiv für Mikrobiologie 84: 95-118.

Quilodrán B, I Hinzpeter, E Hormazabal, A Quiroz \& C Shene. 2010. Docosahexaenoic acid (C22:6n-3, DHA) and astaxanthin production by Thraustochytriidae sp. AS4-A1 a native strain with high similitude to Ulkenia sp.: Evaluation of liquid residues from food industry as nutrient sources. Enzyme and Microbial Technology 47: 24-30.

Raghukumar S. 2004. The role of fungi in marine detrital processes. In: Ramaiah N (ed). Marine microbiology: Facets \& opportunities, pp 91-101. National Institute of Oceanography, Goa.

Raghukumar S \& A Gaertner. 1980. Ecology of the thraustochytrids (lower marine fungi) in the Falden Ground and other parts of the North Sea II. Veröffentlichungen des Instituts für Meeresforschung in Bremerhaven 18: 289308.

Ratledge C \& JP Wynn. 2002. The biochemistry and molecular biology of lipid accumulation in oleaginous microorganisms. Advances in Applied Microbiology 51: 151.

Ríos N, G Medina, J Jiménez, C Yánez, MY García, ML Di Bernardo \& M Gualtieri. 2009. Actividad antibacteriana y antifúngica de extractos de algas marinas venezolanas. Revista Peruana de Biología 16(1): 97-100.

Rodher A. 1966. Determinación de carotenoides. Revista de Agroquímica y Tecnología de Alimentos 6(2): 24-27.

Saenge C, B Cheirsilp, TT Suksaroge \& T Bourtoom. 2011. Potential use of oleaginous red yeast Rhodotorula glutinis for the bioconversion of crude glycerol from biodiesel plant to lipids and carotenoids. Process Biochemistry 46(1): 210-218.

Scheckenbach F, K Hausmann, C Wylezich, M Weitere \& H Arndt. 2010. Large-scale patterns in biodiversity of microbial eukaryotes from the abyssal sea floor. Proceedings of the National Academy of Sciences 107: 115-120.

Socias C. 2012. Thraustochytridos: un protista fungoide como alternativa biotecnológica marina para la producción sustentable de ácidos grasos poliinsaturados (PUFAs). Tesis de Ingeniero en Biotecnología Marina y Acuicultura, Universidad de Concepción, Concepción, 47 pp.

Tamura K, G Stecher, D Peterson, A Filipski \& S Kumar. 2013. MEGA6: Molecular evolutionary genetics analysis Version 6.0. Molecular Biology and Evolution 30: 27252729. 
Valenzuela A, J Sanhueza \& F Barra. 2012. El aceite de pescado: Ayer un desecho Industrial, hoy un producto de alto valor nutricional. Revista Chilena de Nutrición 39(2): 201-209.

Vicente J, M Galindo, M García \& M Granado. 2008. Bioavailability of heavy metals monitoring water, sediments and fish species from a polluted estuary. Journal of Hazardous Materials 162: 823-836.

Vishniac HS. 1956. On the ecology of the lower marine fungi. The Biological Bulletin 111: 410-414.

Wassef EA, S Chatzifotis, EM Sakr \& NE Saleh. 2010. Effect of two natural carotenoid sources in diets for gilthead seabream, Sparus aurata, on growth and skin coloration. Journal of Applied Aquaculture 22(3): 216-229.

Yaguchi T, S Tanaka, T Yokochi, T Nakahara \& T Higashihara. 1997. Production of high yields of docosahexaenoic acid by Schizochytrium sp. strain SR21. Journal of the American Oil Chemists' Society 74(11): 14311434.
Yamasaki T, T Aki, M Shinozaki, M Taguchi, S Kawamoto \& K Ono. 2006. Utilization of Shochu distillery wastewater for production of polyunsaturated fatty acids and xanthophyll's using thraustochytrid. Journal of Bioscience and Bioengineering 102: 323-327.

Yokoyama R, B Salleh \& D Honda. 2007. Taxonomic rearrangement of the genus Ulkenia sensu lato based on morphology, chemotaxonomical characteristics, and 18S rRNA gene phylogeny (Thraustochytriaceae, Labyrinthulomycetes): emendation for Ulkenia and erection of Botryochytrium, Parietichytrium, and Sicyoidochytrium gen. nov. Mycoscience 48(6): 329-341.

Received 27 October 2014 and accepted 11 August 2015

Editor: Claudia Bustos D. 